\title{
Torulaspora globosa: rhizosphere yeast promoting lettuce growth on seedlings and under field conditions
}

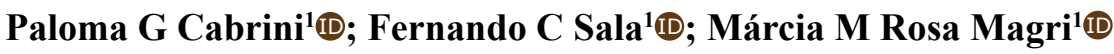

${ }^{1}$ Universidade Federal de São Carlos (UFSCar), Araras-SP, Brasil; palomagc@gmail.com; fcsala@ufscar.br; marcia.magri@ufscar.br

\begin{abstract}
Among soil microorganisms, one group stands out as beneficial to agricultural activities: a plant growth-promoting rhizobacteria (PGPM). These microorganisms support plants through phytohormone production, nutrient provision and plant health maintenance. Among these PGPM, yeasts have a high potential, which is still not very well known.This study aimed to evaluate the effect of inoculation with the rhizosphere yeast Torulaspora globosa (strain 5S55) on development of lettuce (cv. Crocantela). The first research consisted of inoculating seeds with yeast (100 cells/seed), and inoculating seeds, 7 and/or 15 days after emergence (DAE) $\left(1 \times 10^{6}\right.$ cells/plant). The second one consisted of transplanting seedlings from the first experiment to field. Inoculation of seeds and seedlings provided a significant increase of seedling root dry mass; we observed the significant increase of $27 \%$ in productivity of lettuce under field conditions, of shoot fresh mass and a raise of number of leaves per plant. However, studies on inoculation methods, inoculum formulation, cell concentration are essential to optimize the results in growth promotion and to establish technology.
\end{abstract}

Keywords: Lactuca sativa, plant growth promotion, biostimulant, cv. Crocantela.

\section{RESUMO}

Torulaspora globosa: levedura rizosférica promotora de crescimento de alface para produção de mudas e em campo

Micro-organismos promotores de crescimento vegetal (MPCV) auxiliam as plantas pela produção de fitormônios, disponibilização de nutrientes e manutenção da sanidade vegetal. Dentre os MPCV, as leveduras apresentam grande potencial ainda inexplorado. O objetivo deste trabalho foi avaliar a inoculação da levedura rizosférica Torulaspora globosa (linhagem 5S55) no desenvolvimento de alface (cv. Crocantela). O primeiro experimento consistiu na inoculação de sementes nuas com a levedura (100 células/semente), e na inoculação das mudas, 7 e/ou 15 dias após a emergência (DAE) (1x10 células/ planta). O segundo experimento consistiu no transplante das mudas do primeiro experimento para o campo. A inoculação das sementes e mudas proporcionou aumento significativo de massa seca de raízes das mudas; foi observado incremento significativo de produtividade na produção de alface em campo, com incremento de $27 \%$ da massa fresca da parte aérea, com aumento no número médio de folhas por planta. Estudos relacionados a métodos de inoculação, formulações do inóculo, concentração de células, porém, são imperativos para otimizar os resultados de promoção de crescimento e para o estabelecimento da tecnologia.

Palavras-chave: Lactuca sativa, promoção de crescimento vegetal, bioestimulante, cv. Crocantela.

Received on December 6, 2018; accepted on May 31, 2019

$\mathrm{A}$ more sustainable approach, considering techniques used in agriculture, would be the use of plant growth-promoting microorganisms (PGPM), and the benefits for plants with the use of these promoters (Lugtenberg et al., 2002). Several positive results were observed using PGPM species for cultivation in a controlled environment; In field, however, several factors may influence the results, such as abiotic stresses, competition with native microbiota, the specificity between microorganisms and plant species or varieties, among other aspects (Tabassum et al., 2017). Thus, few well established technological options using PGPM in agronomical management of crops in field can be found (Clemente et al., 2016). Among established technologies, currently used by producers, biological nitrogen fixation using rhizobium species stands out (Hungria et al., 2006), and in grass, the bacterium Azospirillum brasilense (Zeffa et al., 2019). We could also cite the use of some bacterial species of the genus Bacillus in order to control phytopathogens and pests (Fira et al., 2018).

PGPM naturally inhabit soil and plants, show mechanisms to promote plant growth ranging from defending plants against diseases and pests, increasing nutrient uptake, producing phytonutrients, and even inducing plant resistance against biotic and abiotic stresses (Odoh, 2017). Among plant growth promotion mechanisms, phytonutrient production, especially indoleacetic acid (IAA), belonging to auxin group, is known for providing a direct effect on plant growth, mainly through stimulating hairy roots development and increasing root dry mass (Ludwig-Müller, 2015). Bacteria, yeast and filamentous fungi are able to produce significant amounts of IAA, being described as microbial groups 
belonging to PGPM (Shao et al., 2015; Sarabia et al., 2018).

Yeasts are naturally present in soil, rhizosphere and plant tissues. However, few studies on this group (such as PGPM), comparing to reported studies on bacteria and filamentous fungi, can be found (Nassar et al., 2005). The yeast Torulaspora globosa was isolated from sugarcane rhizosphere, and is able to produce plant growth promoters, like IAA, phosphate-solubilizing organic acids (Rosa, 2009; Rosa-Magri et al., 2012; Oliveira et al., 2019), and control phytopathogens (Rosa et al., 2010). Few studies on isolation, selection and use of plant growth-promoting yeasts can be found in Brazil, and no study on inoculation effect of this species on plants was published.

Lettuce is the most commercialized leaf vegetable in Brazil. This crop is more adapted to mild climate (Fernandes et al., 2002). Thus, several breeding programs have been carried out aiming to develop cultivars adapted to Brazilian weather. Cv "Crocantela" was developed at Universidade Federal de São Carlos (UFSCar), in Centro de Ciências Agrárias, This cultivar is adapted to warm weather, shows intermediate characteristics between crispy head and head lettuce, is resistant to several diseases and has short cultivation cycle (Sala \& Costa, 2012; UFSCar, 2013). Taking into consideration these crop characteristics, importance of lettuce to Brazilian horticulture, and PGPM potential for plant health maintenance and resistance to stress. The aim of this study was to evaluate the inoculation effect of seeds and seedlings of lettuce, cv Crocantela, with rhizosphere yeast Torulaspora globosa (strain 5S55) on seedling development, grown in a greenhouse, and development of plants transplanted to field.

\section{MATERIAL AND METHODS}

\section{Biological material}

The evaluated yeast belongs to the species Torulaspora globosa (strain 5S55); the strain was isolated in the campus, in Araras, of Centro de Ciências Agrárias, at Universidade Federal de
São Carlos $\left(22^{\circ} 21^{\prime} 25^{\prime \prime}\right.$ S, 47 $23^{\circ} 03^{\prime \prime} \mathrm{W}$, altitude $629 \mathrm{~m}$ ) and stood out due to its high production of IAA (over $800 \mu \mathrm{g} \mathrm{mL}^{-1}$ in 24 hours incubation) and its ability to solubilize calcium phosphate in vitro (Oliveira et al., 2019). The strain was identified through molecular biological techniques, sequencing of the D1/D2 region of the $28 \mathrm{~S}$ rDNA, using primers NL1( $5^{\prime}$ TATCAATAAGCGGAGGAAAAG-3') and NL4 (5'-GGTCCGTGTTT CAAGACGG-3') (Kurtzman \& Robnett, 1998).

The strain $5 \mathrm{~S} 55$ is part of microorganism bank in Laboratório de Microbiologia Agrícola e Molecular (LAMAM), at Universidade Federal de São Carlos, Centro de Ciências Agrárias, campus Araras-SP; the yeast was multiplied in potato broth medium (BD), Difco, during 48 hours, $150 \mathrm{rpm}$, $25^{\circ} \mathrm{C}$. The yeast was centrifuged $(3000$ rpm during 5 minutes). Supernatant was removed and the cells were resuspended in saline solution $(0.85 \% \mathrm{NaCl})$ and used as inoculum in the experiments.

Lettuce (Lactuca sativa), cultivar Crocantela, was used in the experiments. Naked seeds were provided by Fercam ${ }^{\circledR}$ company and used in tests without pesticide in order to avoid any influence on viability of inoculated yeast cells.

Evaluation of lettuce seedling development using seeds inoculated with T. globosa (5S55)

The experiment was carried out in April and May 2017, in a greenhouse at Centro de Ciências Agrárias, Universidade Federal de São Carlos, campus Araras-SP. Average annual rainfall in this area during April and May was 77 and $69 \mathrm{~mm}$, respectively. Minimum and maximum air temperature was 14 and $26^{\circ} \mathrm{C}$.

Before inoculation, seeds were disinfected with sodium hypochlorite ( $0.6 \%$ active chlorine), followed by several washes with sterile distilled water to remove excess chlorine. We used 3200 seeds throughout the experiment, considering that half of this amount was inoculated with yeast cells. Inoculation consisted of a mixture of $2 \mathrm{~mL}$ of a suspension of cells, concentration $1 \times 10^{6}$ cells $/ \mathrm{mL}$ in $20 \mathrm{~g}$ of seeds, approximately 100 cells per seed.
The mixture was done in a small plastic bag, with sterile interior, to facilitate homogeneous distribution of the cell suspension in the seeds. Non-inoculated seeds (control treatment) were treated using only sterile saline solution, in the same conditions described above.

Sowing was performed in coconut fiber substrate, Amafibra ${ }^{\circledR}$, distributed in plastic trays with 200 cells, considering one seed per cell, 1-cm depth. After sowing, the trays were kept in a greenhouse. Substrate moisture was kept at field capacity, water was replaced according to the crop needs using intermittent micro-sprinkler irrigation. Fertigation was done three times a week, with $1 \mathrm{~L}$ hydroponic lettuce/nutrient tray, $0.5 \mathrm{~g} \mathrm{~L}^{-1}$ calcium nitrate, $0.5 \mathrm{~g} \mathrm{~L}^{-1}$ potassium nitrate, $0.35 \mathrm{~g} \mathrm{~L}^{-1}$ magnesium sulfate, $0.1 \mathrm{~g} \mathrm{MAP} \mathrm{L}^{-1}$ and $0.03 \mathrm{~g} \mathrm{~L}^{-1}$ of micronutrients $\left(\right.$ ConMicros $\left.^{\circledR}\right)$. After plant emergence, the authors performed new inoculations of yeast cells at seven and/or fifteen days after emergence of lettuce seedlings. Seedling inoculation was performed individually, being applied $1 \mathrm{~mL}$ yeast suspension per plant, with $1 \times 10^{6}$ cells $/ \mathrm{mL}$. In non-inoculation treatments, the same quantity of sterile saline solution $(0.85 \% \mathrm{NaCl})$ was applied.

A total of eight treatments were considered: $\mathrm{T} 1=$ non-inoculated treatment (control); $\mathrm{T} 2=$ non-inoculated seeds; inoculated plants seven DAE (days after emergence); T3= noninoculated seeds; inoculated plants fifteen DAE; T4= non-inoculated seeds; inoculated plants seven and fifteen DAE; T5 $=$ only inoculated seeds; $\mathrm{T} 6=$ inoculated seeds; inoculated plants seven DAE; T7 = inoculated seeds; inoculated plants fifteen DAE; T8= inoculated seeds; inoculated plants seven and fifteen DAE. Four replicates of 100 plants per treatment were used.

After seedling development, 30 days after emergence, ten plants per plot (40 plants per treatment) were randomly sampled. The authors evaluated shoot height, root length, width and length of leaves, with the aid of a ruler. Besides, number of leaves, fresh mass of root and shoot, dry mass of root and shoot were determined; in order to obtain plant mass, we use an analytical scale, and to 
determine dry mass, plants were dried in an oven, at $60^{\circ} \mathrm{C}$, until constant weight.

Evaluation of lettuce development in field using seedlings inoculated with T. globosa (5S55)

Seedlings were transplanted into field, in an area of Centro de Ciências Agrárias, Universidade Federal de São Carlos, campus Araras-SP, in the same rainfall and temperature conditions described in the previous item. Soil was classified as Typic Paleudult, clayey texture (Yoshida \& Stolf, 2016), and prepared through subsoiling, then harrowed and seedbeds prepared with a plow. Fertilization was done with 150 g 04-14-08 NPK per square meter seedbed, applied and incorporated to soil seven days before transplanting; after twelve days, top dressing fertilization (10 g/plant of 20-00-20 NPK) was applied.

Seedlings used in this experiment were obtained from the experiment described in the previous item. The experimental design was randomized blocks, with four blocks per treatment (eight treatments belonged to the previous experiment), with 20 plants/ block. Transplanted seedlings were sampled from trays randomly obtained and planted using spacing $25 \mathrm{~cm}$ between lines, and $30 \mathrm{~cm}$ between plants.

Plants were kept in field during 63 days under sprinkler irrigation with 200 $\mathrm{L} \mathrm{h}^{-1}$ flow, until horticultural point. At the end of the experiment, five plants per block were evaluated (20 plants per treatment). We evaluated shoot height of the harvested plants (measuring the stem base up to the greater measurement of the plant) size and width of leaves, stem size, using a ruler. Number of leaves, fresh and dry mass of shoot were also evaluated; in order to obtain plant mass. The authors used a semianalytical scale and plants were dried in an oven, at $60^{\circ} \mathrm{C}$, until constant weight, for determining dry mass.

\section{Statistical analysis}

Obtained data were submitted to variance analysis (ANOVA) and averages compared using LSD test (Fisher) at 5\% significance. Analyses were performed using statistical software Statistica V.7.

\section{RESULTS AND DISCUSSION}

The results found in this experiment showed that root length presented lower values for treatment 8 (inoculation of seeds and seedlings seven and fifteen DAE). The same plants, however, presented values of root dry mass superior to non-inoculated plants (Table 1). This result indicates that despite being shorter, roots presented greater branching. The inoculation with yeast in the plant several times probably provided high concentration of microorganism cells in the rhizosphere, which stimulated root branching. Changing root architecture brings benefits as it provides greater surface area for nutrient uptake. This phenomenon is reported in literature as an expected effect of the inoculation with plant growth promoter microorganisms (Idris et al., 2007; Taiz \& Zeiger, 2009).

Considering shoot growth of lettuce seedlings, the results showed that treatment 8 provided significant increase of dry mass, and also wider and longer leaves. Significant reduction in the average number of leaves per seedling was noticed, though. We observed that inoculation with yeast provided less voluminous plants, longer and bigger plants, though. This fact reflected in the results of shoot dry mass (Table 1).

Inoculation of plants with AIA producing microorganisms is described as an efficient growth promotion of several crops. Corn plants inoculated with AIA producing bacteria (Chryseobacterium sp. and Flavobacterium sp. and Burkholderia contaminans) promoted significant increase of shoot and root dry mass (Tagele et al., 2018; Youseif, 2018). Radhakrishnan \& Lee (2016) inoculated lettuce plants with the bacterium Bacillus methylotrophicus, which produces IAA, and observed plant growth promotion, highlighted, mainly, by fresh mass gain.

Despite the prominence of rhizobacteria as plant growth promoters, some species of rhizosphere yeasts are able to produce IAA, and present satisfactory results in growth promotion of several crops: we can mention the species Williopsis saturnus (yeast 4), endophytic of maize and producer of
IAA, which promoted corn growth (shoot and root) in greenhouse trials (Nassar et al., 2005). Amprayn et al. (2012) evaluated the effect of yeast species Candida tropicalis (CtHY), also an IAA producer, on rice development, and observed $35 \%$ increase in root dry mass.

Among growth promotion mechanisms reported associated with yeast, IAA production and phosphate solubilization are the most directly active. For the strain evaluated in this study, high production of IAA and significant phosphate solubilization were observed, both in vitro (Oliveira et al., 2019). However, other mechanisms have not been evaluated yet (production of other plant hormone and other compounds of secondary metabolism) may be acting to stimulate plant development. Thus, it is not possible to say which mechanism is responsible for the observed results.

No study on yeast inoculation in lettuce can be found in literature. In this study, the results for lettuce seedlings, both for shoot and root, showed that plants needed to be yeastinoculated, at least, at three different moments (in the seeds, and in the seedlings seven and fifteen DAE) for obtaining an effect superior to the control treatment (without inoculation) in plant development. Due to the fact that studies on inoculation with yeasts in plants are scarce, no information on the competence of this group to establish itself in the rhizosphere is available; therefore, more in-depth studies are needed to evaluate the ability of a microorganism to resist edaphic conditions (low nutrient concentration, abrupt changes in soil physical and chemical characteristics), to compete with other rhizosphere microorganisms, as well as the ability to stimulate the production of root exudates by the plant.

The results obtained from fieldharvested plants, since seeds and inoculated seedlings showed that treatments with only one inoculation (in the seed, in seven or fifteenDAE seedlings) were the ones which presented the best results in the evaluated parameters (treatments 2, 3 and 5). For shoot length, plants which 
were inoculated only seven DAE (treatment 2) presented higher values; the same result was observed for number of leaves. Treatment 2 also provided larger (longer) leaves compared to non-inoculated plants (Table 2). For shoot fresh mass, plants whose seeds were inoculated at $15 \mathrm{DAE}$ presented a statistically superior result compared to non-inoculated plants, providing $27 \%$ increase in the production of fresh mass (Figure 1). In general, noninoculated plants (treatment 1) showed lower average values in all evaluated parameters. No difference was observed between treatments for stem length and shoot dry mass.
It is important to highlight that results obtained for lettuce seedlings were not the same for plants grown in field. Seedlings from treatment 8 , which presented the best results [values superior to the control (without inoculation) in dry mass for both shoot and root] did not present the best results for plants grown in field. In spite of this, plants generated with seed inoculation or that received seedling inoculation (seven or fifteen DAE) showed an increase in development when compared to noninoculated plants (treatment 1). This result indicates that the $T$. globosa yeast was efficient in promoting lettuce development. However, the ability of yeast to establish in plant root is considered an imperative factor for an increase in plant development. This result was not determined in this study, though.

Many microorganisms have specificity related to their association with some plant species, which allows their establishment in the rhizosphere, and their response to environmental stimuli (Tabassum et al., 2017); thus, the results may vary depending on the inoculated species or cultivar. In this study, cultivar Crocantela was chosen for being new, and due to the fact that no studies on response to inoculation with PGPM can be found. Many microorganisms can promote plant

Table 1. Development parameters of lettuce seedlings grown in greenhouse, inoculated and non-inoculated with the yeast $T$. globosa (5S55) in different stages. Araras, UFSCar, 2017.

\begin{tabular}{|c|c|c|c|c|c|c|c|}
\hline \multirow{2}{*}{ Inoculation } & CPA & $\mathbf{C R}$ & $\mathbf{L F}$ & $\mathbf{C F}$ & MSPA & MSR & \multirow{2}{*}{ NL } \\
\hline & \multicolumn{4}{|c|}{$(\mathrm{cm})$} & \multicolumn{2}{|c|}{ (g) } & \\
\hline seed (-), 7 DAE (-), 15 DAE (-) & $3.56^{1}$ & $8.42 \mathrm{ab}^{2}$ & $1.99 \mathrm{~b}$ & $3.46 \mathrm{~b}$ & $0.035 \mathrm{~b}$ & $0.025 \mathrm{~b}$ & $3.47 \mathrm{ab}$ \\
\hline seed (-), 7 DAE (+), 15 DAE (-) & 3.61 & $8.66 \mathrm{ab}$ & $2.06 \mathrm{~b}$ & $3.41 \mathrm{~b}$ & $0.033 \mathrm{~b}$ & $0.026 \mathrm{~b}$ & $3.53 \mathrm{ab}$ \\
\hline seed (-), 7 DAE (-), 15 DAE (+) & 3.53 & $8.39 \mathrm{ab}$ & $2.20 \mathrm{ab}$ & $3.28 \mathrm{~b}$ & $0.034 \mathrm{~b}$ & $0.028 \mathrm{~b}$ & $3.37 \mathrm{ab}$ \\
\hline seed $(-), 7 \mathrm{DAE}(+), 15 \mathrm{DAE}(+)$ & 3.53 & $8.62 \mathrm{ab}$ & $2.08 \mathrm{~b}$ & $3.41 \mathrm{~b}$ & $0.033 \mathrm{~b}$ & $0.025 \mathrm{~b}$ & $3.53 \mathrm{ab}$ \\
\hline seed (+), 7 DAE (-), 15 DAE (-) & 3.77 & $8.27 \mathrm{ab}$ & $2.14 \mathrm{ab}$ & $3.65 \mathrm{ab}$ & $0.036 \mathrm{~b}$ & $0.026 \mathrm{~b}$ & $3.47 \mathrm{ab}$ \\
\hline seed $(+), 7 \mathrm{DAE}(+), 15 \mathrm{DAE}(+)$ & 3.70 & $8.69 \mathrm{ab}$ & $2.15 \mathrm{ab}$ & $3.70 \mathrm{ab}$ & $0.037 \mathrm{ab}$ & $0.029 \mathrm{ab}$ & $3.73 \mathrm{a}$ \\
\hline seed $(+), 7$ DAE $(-), 15$ DAE $(+)$ & 3.64 & $9.13 \mathrm{a}$ & $2.13 \mathrm{ab}$ & $3.47 \mathrm{~b}$ & $0.034 \mathrm{~b}$ & $0.026 \mathrm{~b}$ & $3.20 \mathrm{~b}$ \\
\hline seed $(+), 7$ DAE $(-), 15$ DAE $(+)$ & 3.81 & $7.71 \mathrm{~b}$ & $2.40 \mathrm{a}$ & $4.08 \mathrm{a}$ & $0.042 \mathrm{a}$ & $0.033 \mathrm{a}$ & $3.17 \mathrm{~b}$ \\
\hline CV (\%) & 9.27 & 7.35 & 8.47 & 10.31 & 11.67 & 12.01 & 7.67 \\
\hline
\end{tabular}

parameter without statistical difference; ${ }^{2}$ same letters among data in the column do not differ significantly among each other, Fisher test (5\%); $\mathrm{DAE}=$ days after emergence; $\mathrm{CPA}=$ shoot length; $\mathrm{CR}=$ root length; $\mathrm{LF}=$ leaf width; $\mathrm{CF}=$ leaf length; $\mathrm{MSPA}=$ shoot dry mass; $\mathrm{MSR}=$ root dry mass; $\mathrm{NL}=$ number of leaves.

Table 2. Development parameters of lettuce seedling grown in the field, from seedlings inoculated and non-inoculated with the yeast $T$. globosa in different stages. Araras, UFSCar, 2017.

\begin{tabular}{|c|c|c|c|c|c|c|}
\hline \multirow{2}{*}{ Inoculation } & CPA & $\mathbf{C F}$ & $\mathrm{CC}$ & MFPA & MSR & \multirow{2}{*}{ NL } \\
\hline & \multicolumn{3}{|c|}{$(\mathrm{cm})$} & \multicolumn{2}{|c|}{ (g) } & \\
\hline seed (-),7 DAE (-),15 DAE (-) & $22.00 c^{2}$ & $25.63 \mathrm{~b}$ & $2.75^{1}$ & $334.50 \mathrm{~b}$ & $14.11^{1}$ & $14.50 \mathrm{~b}$ \\
\hline seed (-), 7 DAE (+), 15 DAE (-) & $24.17 \mathrm{ab}$ & $28.46 \mathrm{a}$ & 3.50 & $407.33 \mathrm{ab}$ & 16.42 & $16.33 \mathrm{a}$ \\
\hline seed (-), 7 DAE (-),15 DAE $(+)$ & $22.50 \mathrm{abc}$ & $26.00 \mathrm{ab}$ & 3.00 & $360.67 \mathrm{ab}$ & 14.08 & $16.67 \mathrm{a}$ \\
\hline seed $(-), 7$ DAE $(+), 15$ DAE $(+)$ & $22.08 \mathrm{bc}$ & $26.21 \mathrm{ab}$ & 2,96 & $359.42 \mathrm{ab}$ & 17.57 & $15.33 \mathrm{ab}$ \\
\hline seed (+), 7 DAE (-), 15 DAE (-) & $24.62 \mathrm{a}$ & $27.08 \mathrm{ab}$ & 3.08 & $402.17 \mathrm{ab}$ & 18.25 & $16.25 \mathrm{a}$ \\
\hline seed $(+), 7$ DAE $(+), 15$ DAE $(+)$ & $23.29 \mathrm{abc}$ & $27.00 \mathrm{ab}$ & 3.17 & $382.83 \mathrm{ab}$ & 16.83 & $16.00 \mathrm{ab}$ \\
\hline seed $(+), 7$ DAE $(-), 15$ DAE $(+)$ & $23.42 \mathrm{abc}$ & $27.50 \mathrm{ab}$ & 3.29 & $425.33 \mathrm{a}$ & 18.56 & $16.42 \mathrm{a}$ \\
\hline seed $(+), 7$ DAE $(-), 15$ DAE $(+)$ & $23.25 \mathrm{abc}$ & $27.54 \mathrm{ab}$ & 2.96 & $383.17 \mathrm{ab}$ & 16.44 & $15.92 \mathrm{ab}$ \\
\hline CV (\%) & 5.89 & 6.23 & 14.04 & 13.31 & 22.10 & 6.42 \\
\hline
\end{tabular}

${ }^{1}$ parameter without statistical difference; ${ }^{2}$ same letters among data in the column do not differ significantly among each other, Fisher test $(5 \%) ; \mathrm{DAE}=$ days after emergence; $\mathrm{CPA}=$ shoot length $\mathrm{CF}=$ leaf length; $\mathrm{CC}=$ stem length; $\mathrm{MFPA}=$ shoot fresh mass; $\mathrm{MSR}=$ root dry mass; $\mathrm{NL}=$ number of leaves. 


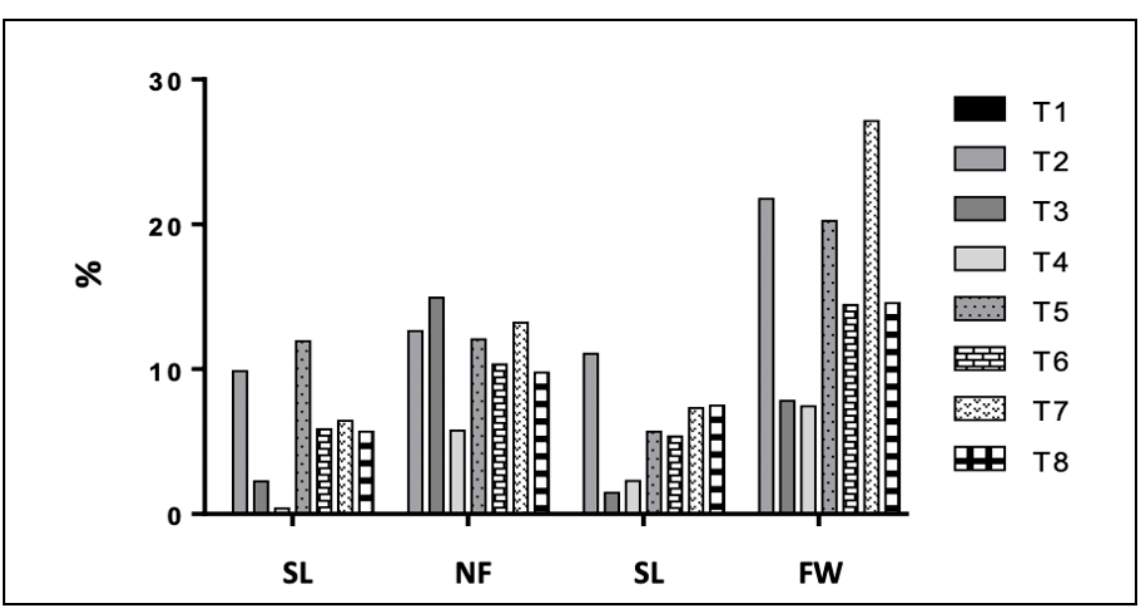

T1= seed (-) 7 DAE (days after emergence) (-) 15 DAE (-); T2= seed (-) 7 DAE (+) 15 DAE $(-)$; T3 $=$ seed $(-) 7 \mathrm{DAE}(-) 15 \mathrm{DAE}(+)$; $\mathrm{T} 4=\operatorname{seed}(-) 7 \mathrm{DAE}(+) 15 \mathrm{DAE}(+)$; $\mathrm{T} 5=$ seed $(+)$ 7 DAE (-) 15 DAE (-); T6= seed (+) 7 DAE (+) 15 DAE (-); T7= seed (+) 7 DAE (-) 15 $\mathrm{DAE}(+)$; $\mathrm{T} 8=$ seed $(+) 7 \mathrm{DAE}(+) 15 \mathrm{DAE}(+) . \mathrm{SL}=$ shoot length; $\mathrm{NF}=$ number of leaves; $\mathrm{FW}=$ fresh weight.

Figure 1. Increase (\%) obtained in treatments with inoculation of yeast $T$. globosa, compared with control treatment. Araras, UFSCar, 2017.

growth in several crops (cosmopolitan species), such as bacterium Azospirillum brasilense. This species of diazotrophic bacteria has been isolated from several crops, such as maize and rice, and currently several studies have confirmed its efficiency as growth promoter in different crops (Cassán \& Dias-Zorita, 2016), as in common bean (Remans et al., 2008). For lettuce, inoculation with Azospirillum brasilense promoted an increase in germination rate and stimulated growth after saline stress, with the increase in number of leaves, plant height and root length (Barassi et al., 2006; Mangmang et al., 2015).

Nevertheless, no studies on yeast inoculation in plants and evaluation of their specificity related to growth promotion in different plant species can be found. The action of the yeast T. globosa (5S55), evaluated in this work as a plant-growth promoter, was previously evaluated by Oliveira et al. (2019), who observed that inoculation with yeast cells in transplanted tomato seedlings promoted significant increase in dry mass of the plants in greenhouse cultivation. These data may indicate that yeast may be used in different crops. More detailed studies using other species and other cultivars are necessary to confirm this fact, considering that this was not the aim of this study.

The authors also highlight that the results found in this study were obtained from the simple inoculation with T. globosa (5S55) cells in seeds and seedlings of lettuce, in an environment without control (greenhouse and field). The used inoculum consisted of nothing but cells, that is, the use of a formulation that provided some types of cell protection, or addition of nutrients to favor the establishment of yeast in plants was not evaluated.

We can conclude that inoculation in seeds and seedlings of lettuce, cv. Crocantela, with $T$. globosa rhizosphere yeast (strain 5S55) provided an increase in root dry mass, and a significant increase in lettuce production, under field conditions. Considering the need to carry out some experiments which evaluate inoculation, cell concentration in the inoculum and formulation development is important. In addition, we consider the need to evaluate the establishment of the species in roots through its re-isolation in selective media, or with the use of molecular markers.

\section{ACKNOWLEDGEMENTS}

This study was financed in part by Coordenação de Aperfeiçoamento de Pessoal de Nível Superior - Brasil
(CAPES) - Finance Code 001.

\section{REFERENCES}

AMPRAYN, K; ROSE, MR; KECSKÉS, M; PEREG, L; NGUYENM, HT; KENNEDY, IR. 2012. Plant growth promoting characteristics of soil yeast (Candida tropicalis $\mathrm{HY}$ ) and its effectiveness for promoting rice growth. Applied Soil Ecology 61: 295-299.

BARASSI, CA; AYRAULT, G; CREUS, CM; SUELDO, RJ; SOBRERO, MT. 2006. Seed inoculation with Azospirillum mitigates $\mathrm{NaCl}$ effects on lettuce. Scientia Horticulturae, 109: 8-14.

CASSÁN, F; DIAZ-ZORITA, M. 2016. Azospirilllum sp. in current agriculture: From the laboratory to the field. Soil Biology \& Biochemistry 103: 117-130.

CLEMENTE, JM; CARDOSO, CR.; VIEIRA, BS; FLO, IM; COSTA, RL. 2016. Use of Bacillus spp. as growth promoter in carrot crop. African Journal of Agricultural Research 11: 3355-3359.

FERNANDES, AA; MARTINEZ, HEP; PEREIRA, PRG; FONSECA, MCM. 2002. Produtividade, acúmulo de nitrato e estado nutricional de cultivares de alface, em hidroponia, em função de fontes de nutrientes. Horticultura Brasileira20: 195-200.

FIRA, D; DIMKIC, I; BERIC, T; LOZO, J; STANKOVIC, S. 2018. Biological control of plant pathogens by Bacillus species. Journal of Biotechnology 285: 44-55.

HUNGRIA, M; CAMPO, RJ; MENDES, IC; GRAHAM, PH. 2006. Contribution of biological nitrogen fixation to the $\mathrm{N}$ nutrition of grain crops in the tropics: The success of soybean (Glycine max L. Merr.) in South America. In: SINGH, RP; SHANKAR, N; JAIWA, PK (eds). Nitrogen Nutrition and Sustainable Plant Productivity, Houston: Studium Press. 43-93.

IDRIS, EE; IGLESIAS, DJ; TALON, M; BORRISS, R. 2007. Tryptophan-dependent production of indole-3-acetic acid (IAA) affects level of plant growth promotion by Bacillus amyloliquefaciens FZB42. Molecular Plant-Microbe Interactions 20: 619-626.

KURTZMAN, CP; ROBNETT, CJ. 1998. Identification and phylogeny of ascomycetous yeast from analysis of nuclear large subunit (26S) ribosomal DNA partial sequences. Antonie van Leeuwenhoek 73: 331-371.

LUDWIG-MÜLLER, J. 2015. Bacteria and fungi controlling plant growth by manipulating auxin: balance between development and defense. Journal of Plant Physiology 172: 4-12.

LUGTENBERG, BJJ; CHIN-A-WOENG, TFC; BLOEMBERG, GV. 2002. Microbe-plant interactions: principles and mechanisms. Antonie van Leeuwenhoek 81: 373-383.

MANGMANG, JS.; DEAKER, R; ROGERS, G. 2015. Early seedling growth response of lettuce, tomato and cucumber to Azospirillum brasilense inoculated by soaking and drenching. Horticultural Science 42: 37-46. 
N A S S A R, A; E L - T A R A L I B Y, K ; SIVASITHAMPARAM, K. 2005. Promotion of plant growth by an auxin-producing isolate of the yeast Williopsis saturnus endophytic in maize (Zea mays L.) roots. Biology and Fertility of Soils 42: 97-108.

ODOH, CK. 2017. Plant growth promoting rhizobacteria (MPCV): a bioprotectant bioinoculant for sustainable agrobiology. A review.International Journal of Advanced Research in Biological Sciences 4: 123-142.

OLIVEIRA, BT; BIZARRIA JUNIOR, R; SILVA, LG; ROSA-MAGRI, MM. 2019.Rhizosphere yeast Torulaspora globosa with plant growth promotion traits and improvement of the development of tomato seedlings under greenhouse conditions. African Journal of Agricultural Research 14: 935-942.

RADHAKRISHNAN, R; LEE, IJ. 2016. Gibberellins producing Bacillus methylotrophycus KE2 supports plant growth and enhances nutritional metabolites and food values of lettuce. Plant Physiology and Biochemistry 109: 181-189.

REMANS, R; BEEBE, S; BLAIR, M; MANRIQUE, G; TOVAR, E; RAO, I; CROONENBORGHS, A; GUTIERREZTORRES, R; EL-HOWEITY, M; MICHIELS, VANDERLEYDEN, J. 2008. Physiological and genetic analysis of root responsiveness to auxin-producing plant growth-promoting bacteria in common bean (Phaseolus vulgaris
L.). Plant and Soil 302: 149-161.

ROSA, MM. 2009. Avaliação de leveduras isoladas de áreas agrícolas como agentes no controle biológico de fitopatógenos. 151p. Rio Claro: UNESP. (Ph.D. Thesis).

ROSA, MM; TAUK-TORNISIELO, SM, RAMPAZZO, PE; CECCATO-ANTONINI, SR. 2010. Evaluation of the biological control by yeast Torulaspora globosa against Colletotrichum sublineolum in sorghum. World Journal of Microbiology and Biotechnology 26: 1491-1502.

ROSA-MAGRI, MM; AVANSINI, SH; LOPESASSAD, ML; TAUK-TORNISIELO, SM; CECCATO-ANTONINI, SR. 2012. Release of potassium from rock powder by the yeast Torulaspora globosa. Brazilian Archives of Biology and Technology 55: 577-582.

SALA, FC; COSTA, CP. 2012. Retrospectiva e tendência da alfacicultura brasileira. Horticultura Brasileira 30:187-194.

SARABIA, M; CAZARES, S; GONZÁLEZRODRÍGUEZ, A; MORA, F; CARREÓNABUD, Y; LARSEN, J. 2018. Plant growth promotion traits of rhizosphere yeasts and their response to soil characteristics and crop cycle in maize agroecosystems.Rhizosphere 6: 67-73.

SHAO, J; XU, Z; ZHANG, N; SHEN, Q; ZHANG, R. 2015. Contribution of indole3 -acetic acid in the plant growth promotion by the rhizosphere strain Bacillus amylo liquefaciens SQR9. Biology and Fertility of Soils 51: 321-330.

TABASSUM, B; KHANB, A; TARIGA, M; RAMZANC, M; KHANA, MSI; SHAHIDA, N; AALIYAA, K. 2017. Bottlenecks in commercialization and future prospects of MPCV. Applied Soil Ecology 121: 102-117.

TAGELE, SB; KIM, SW; LEE, HG; KIM, HS; LEE, YS. 2018. Effectiveness of multi-trait Burkholderia contaminants KNY17BI1 in growth promotion and management of banded leaf and sheath blight in maize seedling. Microbiological Research 214: 8-18.

TAIZ, L; ZEIGER, E. 2009. Fisiologia Vegetal. Artmed Editora. 848p.

UFSCar. 2013. UFSCar desenvolve nova cultivar de alface. Informativo FAI-UFSCar 133:3.

YOUSEIF, SH. 2018. Genetic diversity of plant growth promoting rhizobacteria and their effects on the growth of maize plants under greenhouse conditions. Annals of Agricultural Sciences 63: 25-35.

YOSHIDA, FA; STOLF, R. 2016. Mapeamento digital de atributos e classes de solo da UFSCarAraras/SP. Revista Ciência, Tecnologia \& Ambiente 3: 1-11.

ZEFFA, DM; PERINI, LJ; SILVA, MB; SOUSA, NV; SCAPIM, CA; OLIVEIRA, ALM; AMARAL JUNIOR, AT; GONÇALVES, LSA. 2019. Azospirillum brasilense promotes increases in growth and nitrogen use efficiency of maize genotypes. PLoS ONE 14: e0215332. doi:10.1371. 